\title{
Analisis Faktor-Faktor yang Mempengaruhi Perubahan Nilai Tukar di Indonesia Tahun 2006-2018
}

\author{
Hariza Hasyim, SE, MSi \\ hariza.hasyim@uin-suska.ac.id
}

\begin{abstract}
Abstrak
Penelitian ini bertujuan untuk meneliti faktor-faktor penentu nilai tukar rupiah selama tahun 2006-2018. Variabel yang digunakan dalam penelitian ini yaitu Pendapatan rill, infasi, cadangan devisa dan suku bunga sebagai variabel independent dan nilai tukar rupiah sebagai variabel dependent, dengan melakukan uji regresi Linear berganda. Berdasarkan uji koefisien determinasi diketahui bahwa variabel bebas (pendapatan rill, inflasi, cadangan devisa dan suku bunga) berpengaruh terhadap variabel terikat (nilai tukar) sebesar 76\% Secara parsial (uji-t) menujukkan Variabel pendapatan rill (X1) dan suku bunga (x4) mimiliki hubungan negatif dan signifikan terhadap kurs (Y). Sedangkan inflasi (X2) memilki hubungan positif dengan kurs dan cdangan devisa (X3)berpengaruh negatif dan tidak signifikan terhadap nilai tukar. Dan Secara simultan (Uji-F) antara variabel bebas (Pendapatan rill, inflasi, cadngan devisa dan suku bunga) terhadap variabel terikat (nilai tukar) menujukkan F-hitung(> F-tabel sehingga dapat disimpulkan bahwa variabel Bebas (pendapatan rill, inflasi ,cadangan devisa dan suku bunga) secara bersama-sama berpengaruh secara signifikan terhadap variabel terikat (nilai tukar rupiah).
\end{abstract}

Kata kunci : Pendapatan rill, inflasi, cadangan devisa, suku bunga dan nilai tukar.

\section{PENDAHULUAN}

\section{Latar belakang masalah}

Berkembang atau tidaknya perekonomian suatu negara tergantung dari kondisi makroekonomi. Salah satu dari indikator makroekonomi tersebut adalah nilai tukar mata uang. Hal ini dikarenakan nilai tukar mata uang adalah perbandingan antara mata nilai uang suatu negara dengan mata uang negara lain. Apabila nilai mata uang suatu negara tersebut menguat, maka bisa dikatakan kondisi ekonomi negara tersebut sedang berkembang dibandingkan negara lain. Sehingga nilai tukar mata uang dapat digunakan sebagai acuan kondisi perekonomian dari suatu negara. 
Nilai tukar mata uang atau tingkat kurs (exchange rate) merupakan salah satu variabel ekonomi makro yang sangat penting, karena pergerakan tingkat kurs dapat mempengaruhi stabilitas dan kegiatan ekonomi, terlebih khusus transaksi ekonomi secara internasional yang meliputi perdagangan dan investasi. Kegiatan perdagangan dan investasi tidak hanya dilakukan antara masyarakat di suatu daerah atau wilayah tertentu, tetapi juga dilakukan antar suatu negara dengan negara lain. Hal ini dilakukan untuk memenuhi berbagai kebutuhan dari suatu negara, yang bisa jadi tidak diproduksi sendiri atau mengalami kekurangan didalam negeri. Untuk itulah maka terjadi perdagangan internasional. Ketidakstabilan nilai tukar atau tingkat kurs ini mampu mempengaruhi arus modal dan perdagangan karena tingkat kurs memfasilitasi transaksi-transaksi perdagangan dan investasi secara internasional. Hal ini disebabkan karena dalam transaksi-transaksi ekonomi secara internasional akan melibatkan penggunaan lebih dari satu mata uang, yakni mata uang domestik dan mata uang asing.

Pergerakan nilai tukar dalam hal ini rupiah terhadap dollar AS, setelah diberlakukannya sistem kurs mengambang bebas (floating exchange rate system) yang dimulai sejak tahun 1997 telah membawa dampak dalam perkembangan ekonomi nasional baik dalam sektor moneter maupun sektor rill. Jika kurs Rupiah (IDR) terhadap dollar AS (USD) tidak stabil maka hal ini akan membuat kurs mengalami fluktuasi. Meningkatnya nilai tukar rupiah terhadap dollar AS karena kekuatan pasar ini disebut sebagai depresiasi rupiah terhadap dollar AS. Sebaliknya, menurunnya nilai tukar rupiah terhadap dollar AS disebut sebagai apresiasi rupiah terhadap dollar AS.

Dalam UU no 23 Tahun 1999 tentang Bank Indonesia sebagaimana telah diamandemen dengan UU No 3 Tahun 2004 pada pasal 7 mengatakan bahwa Indonesia telah menganut kebijakan moneter dengan tujuan tunggal yakni mencapai dan memelihara kestabilan nilai tukar rupiah. Kurs dapat dijadikan alat untuk mengukur kondisi perekonomian suatu negara. Sistem devisa bebas dan ditambah dengan penerapan sistem mengambang bebas di Indonesia sejak tahun 1997, menyebabkan pergerakan nilai tukar di pasar menjadi sangat rentan oleh pengaruh faktor-faktor ekonomi maupun non ekonomi, diantaranya arus modal atau investasi perdagangan internasional dan keadaan sosial politik pada negara tersebut. Indonesia sebagai negara yang berada pada di tengah perekonomian global juga melakukan kegiatan ekonomi internasional seperti Impor, Ekspor dan lain-lain sehingga jika Indonesia tidak dapat menjaga kestabilan nilai tukar mata uang domestiknya, maka hal ini akan membawa dampak buruk bagi pergerakan roda perekonomian. 
Nilai tukar rupiah semenjak diberlakukannya sistem kurs mengambang bebas terus mengalami depresiasi hingga mencapai nilai terendahnya pada bulan juni 1998 yaitu sebesar Rp.14.900 per dollar AS (USD). Hal ini disebabkan pengaruh krisis moneter yang terjadi pada tahun 1997. Pada tahun 2008 rupiah mengalami depresiasi yang cukup besar yaitu Rp. 11.050/USD akibat dampak dari krisis keuangan global. Pada tahun 2011 rupiah mengalami apresiasi yang cukup besar yang membuat nilai tukar turun sebesar Rp.8.835/USD. Kondisi nilai tukar Indonesia terhada Dollar US untuk triwulan pertama ditahun 2015, sungguh mengkhawatirkan. Niilai tukar rupiah terhadap dollar AS mengalami pelemahan yang relatif besar, yaitu melewati angka Rp. 13. 000/ Dollar US. Dan terakhir data 2018 menunjukkan kurs di level 14.250/Dollar. Angka ini merupakan titik terendah pasca krisis moneter 1998

Secara umum, ada beberapa faktor yang Memengaruhi Perubahan Kurs

\section{a. Sistem Kurs yang Dianut}

Ada tiga macam sistem kurs, yaitu sistem kurs bebas, sistem kurs tetap dan sistem kurs mengambang terkendali. Sistem kurs yang dianut suatu negara sangat mempengaruhi cepat lambatnya perubahan kurs. Pada sistem kurs bebas, kurs sangat mudah berubah. Pada sistem kurs tetap, kurs tidak pernah berubah (kecuali diinginkan oleh pemerintah). Pada sistem kurs mengambang terkendali, perubahan kurs bisa dikendalikan pemerintah.

b. Selera (Cita Rasa) Masyarakat

Selera masyarakat yang meningkat pada produk suatu negara, membuat permintaan terhadap produk negara tersebut juga meningkat. Peningkatan permintaan terhadap produk negara tersebut, tentu akandiikuti oleh peningkatan permintaan terhadap mata uang negara tersebut (untuk membayar impor). Sehingga, nilai tukar mata uang negara tersebut juga akan meningkat. Itu berarti, bila masyarakat Indonesia sangat menyukai produkproduk Amerika maka pada akhirnya akan menaikkan nilai tukar dolar Amerika.

\section{c. Keadaan Neraca Pembayaran}

Apabila neraca pembayaran Indonesia mengalami surplus (lebih), itu berarti telah terjadi kelebihan permintaan terhadap rupiah. Permintaan yang lebih terhadap rupiah akan menyebabkan nilai tukar rupiah mengalami kenaikan sehingga terjadilah perubahan kurs.

\section{d. Adanya Kebijakan Devaluasi dan Revaluasi}

Adanya kebijakan devaluasi dan revaluasi yang dilakukan pemerintah bisa menyebabkan terjadinya perubahan kurs. Karena, yang dimaksud dengan 
devaluasi adalah kebijakan pemerintah melalui bank sentral untuk menurunkan nilai mata uang dalam negeri (rupiah) terhadap mata uang asing dengan tujuan meningkatkan ekspor. Sedangkan revaluasi adalah kebijakan pemerintah melalui bank sentral untuk menaikkan nilai mata uang dalam negeri (rupiah) terhadap mata uang asing karena keadaan ekonomi sudah memungkinkan. Tentang devaluasi dan revaluasi bisa kalian bacalagi di buku Ekonomi kelas X mengenai Kebijakan Moneter.

Selain yang sudah dijelaskan diatas, suku bungan juga berkaitan dengan kurs. Untuk Indonesia Suku bunga sertifikat Bank Indonesia (SBI) cenderung fluktuatif karena mengalami peningkatan dan penurunan secara tidak menentu dari waktu ke waktu. Pada tahun 2009 merupakan titik tertinggi peningkatan suku bunga SBI yaitu sebesar $10.83 \%$ dan titik terendahnya yaitu pada tahun 2012 suku bunga SBI berada pada titik $4.75 \%$. Perkembangan tingkat inflasi di Indonesia menunjukan hasil yang fluktuatif karena megalami kenaikan dan penurunan yang tidak menentu dari waktu ke waktu. Pada tahun2008 berada pada titik tertinggi sebesar 11,06\% karena dampak dari krisis ekonomi global yang menyebabkan inflasi Indonesia ikut bergejolak. Akan tetapi, kondisi laju inflasi Indonesia tahun 2009 ikut membaik dan berada pada posisi terendah yaitu sebesar 2,78\%.

Fluktuasi pada Nilai tukar jugai berdampak pada variabel makroekonomi lainnya seperti inflasi. Tingkat inflasi berfluktuasi searah dengan pertukaran nilai tukar, namun secara keseluruhan masih menunjukan tingkat inflasi yang dikendalikan. Selain itu, pertumbuhan ekonomi juga meningkat seiring dengan depresiasi perlahan pada nilai tukar rupiah. Pertumbuhan ekonomi meningkat disebabkan oleh variabel-variabel dasar makroekonomi yang mendukung seperti ekspor impor, investasi asing menunjukan arah yang menguntungkan. Sedangkan faktor-faktor tersebut juga dipengaruhi oleh fluktuasi nilai tukar. Inflasi adalah merosotnya nilai uang karena banyaknya dan cepatnya uang beredar sehingga menyebabkan naiknya harga barang-barang. Secara sederhana, inflasi kita definisikan sebagai turunnya daya beli uang. Uang dalam jumlah sama seiring waktu tidak mampu untuk membeli barang yang senilai atau sama.

Data inflasi tahunan diperoleh dari Bank Indonesia. Data inflasi jangka panjang sebagai tolok ukur tujuan investasi yang bersifat jangka panjang.

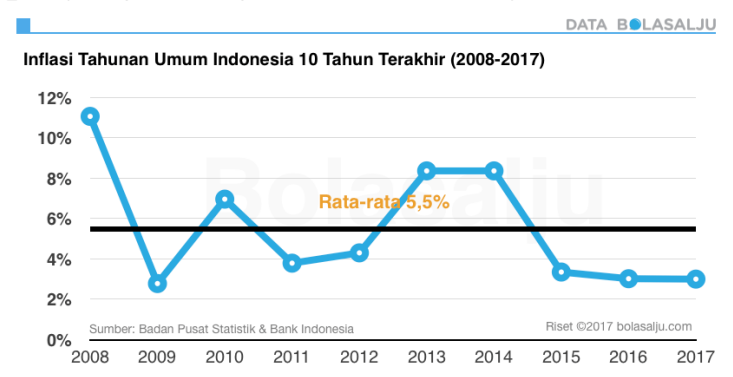


Dari data di atas, mengacu ke periode 2007-2016, rata-rata inflasi tahunan umum Indonesia selama 10 tahun adalah 5,86\% per tahun. Menggunakan kalkulasi akumulasi penurunan nilai setelah inflasi 10 tahun, nilai uang secara akumulatif turun $-45,54 \%$ atau $-5,90 \%$ YoY (year over year). Untuk alasan agar mudah diingat, dalam setiap artikel/diskusi kita bulatkan inflasi tahunan 10 tahun adalah $6 \%$ per tahun.

Inflasi tahunan umum adalah rata-rata kenaikan harga dari seluruh barang yang disurvei oleh Badan Pusat Statistik dalam setahun. Karena bersifat rata-rata inflasi umum, kita harus paham bahwa mungkin ada biaya yang naiknya kurang dari ratarata itu; di sisi lain, ada biaya yang kenaikannya lebih besar dari angka tersebut.

Hubungan antara kurs dengan cadangan devisa dapat dijelaskan melalui mekanisme harga. Menurut teori Keynesian mengatakan bahwa apabila karena suatu hal nilai tukar valuta mengalami apresiasi ( mata uang asing meningkat dan mata uang lokal menurun), maka hal ini secara relatif dapat menyebabkan tingginya harga barang ekspor dibanding harga barang impor. Kondisi ini berpengaruh pada peningkatan ekspor dan penurunan impor. Apabila ekspor lebih besar dari pada impor, maka hal ini dapat menyebabkan surplus pada Neraca Pembayaran Internasional yang selanjutnya akan meningkatkan posisi cadangan devisa suatu negara. Demikian sebaliknya. Oleh karena itu menurut teori Keynesian, dengan asumsi ceteris paribus, hubungan antara kurs dengancadangan devisa adalah negatif,

Keterangan diatas menunjukan bahwa nilai tukar berperan penting dalam menentukan kondisi perekonomian dan variabel-variabel makroekonomi suatu negara. Sehingga dibutuhkan suatu kebijakan yang dapat meredam nilai tukar agar tidak terlalu berfluktuasi. Kebijakan yang tepat tidak dapat ditetapkan begitu saja tanpa mengetahui faktor-faktor apa yang menyebabkan perubahan pada nilai tukar.

Oleh karena itu, kita perlu manganalisis faktor-faktor yang menentukan perubahan nilai tukar rupiah, karena fluktuasi yang berlebihan dapat mempersulit para pengambil keputusan ekonomi makro untuk memprediksi suatu kebijakan makroekonomi. Selain itu bagi dunia usaha, nilai tukar yang fluktuatif dapat mempersulit penentuan tingkat biaya dan keuntungan dimasa depan.

Berdasarkan penjelasan diatas, penulis tertarik untuk melakukan sebuah penelitian dengan judul "Analisis Faktor-Faktor yang Mempengaruhi Perubahan Nilai Tukar di Indonesia Tahun 2006-2018

\section{Perumusan Masalah}

1. Apakah indikator makroekonomi : pendapatan riil, inflasi, cadangan devisa dan tingkat suku bunga secara parsial berpengaruh signifikan terhadap perubahan nilai tukar rupiah ? 
2. Apakah indikator makroekonomi : pendapatan riil, inflasi, cadangan devisa dan tingkat suku bunga secara simultan berpengaruh terhadap perubahan nilai tukar rupiah?

\section{Tujuan Penelitian}

1. Untuk menganalisis pengaruh parsial makroekonomi: pendapatan riil, inflasi, cadangan devisa dan tingkat suku bunga terhadap perubahan nilai tukar rupiah

2. Untuk menganalisis pengaruh simultan kondisi makroekonomi: pendapatan riil, inflasi, dan tingkat suku bunga terhadap perubahan nilai tukar rupiah.

\section{TINJAUAN PUSTAKA}

\section{Inflasi.}

Inflasi merupakan kecenderungan kenaikan harga-harga umum barangbarang yang tidak sesaat. Inflasi adalah kenaikan harga barang-barang yang bersifat umum dan terus-menerus. Rahardja dan Manurung (2008) Secara garis besar inflasi terjadi pada kenaikan harga dan dalam waktu yang lmaa.

Menurut Kuncoro (1998), dalam Raharjo (2009). Inflasi adalah kecenderungan dari harga untuk meningkat secara umum dan terus menerus. Kenaikan harga dari satu atau dua barang tidak dapat disebut inflasi, kecuali bila kenaikan tersebut meluas atau mengakibatkan kenaikan kepada barang lainnya.

\section{Pendapatan Riil.}

Pertumbuhan ekonomi yang tinggi dan prosesnya yang berkelanjutan merupakan kondisi utama bagi kelangsungan pertumbuhan ekonomi. Pertumbuhan ekonomi menunjukan sampai dimana kegiatan perekonomian akan menghasilkan tambahan pendapatan masyarakat pada suatu periode tertentu. Dengan kata lain, perekonomian dikatakan mengalami pertumbuhan bila pendapatan riil masyaraat pada periode tertentu lebih tinggi dari pada pendapatan riil masyarakat pada periode sebelumnya. Dalam pengertian ekonomi makro, pertumbuhan ekonomi adalah penambahan Produk Domestik Bruto (PDB), yang berarti peningkatan pendapatan nasional ( Tambunan, 2001 dalam Theo, 2012 )

\section{Suku Bunga dan Sertifikat Bank Indonesia (SBI)}

Menurut Sukirno (2005), suku bunga adalah persentase pendapatan yang diterima oleh kreditur dari pihak debitur selama interval waktu tertentu. 
Perubahan tingkat suku bunga selanjutnya akan mempengaruhi keinginan untuk mengadakan investasi, misalnya pada surat berharga, dimana harga dapat naik atau turun tergantung pada tingkat bunga (bila tingkat bunga naik maka surat berharga turun dan sebaliknya), sehingga ada kemungkinan pemegang surat berharga akan menderita capital loss atau capital gain.

Pengertian suku bunga menurut Sunariyah (2004) adalah harga dari pinjaman Suku bunga dinyatakan sebagai persentase uang pokok per unit waktu. Bunga merupakan suatu ukuran harga sumber daya yang digunakan oleh debitur yang harus dibayarkan kepada kreditur sedangkan menurut Nopirin (2000) tingkat suku bunga adalah biaya yang harus dibayar oleh peminjam atas pinjaman yang diterima dan merupakan imbalan bagi pemberi pinjaman atas dananya. Sebagaimana dalam UU no 23 Tahun 1999 tentang Bank Indonesia sebagaimana telah diamandemen dengan UU No 3 Tahun 2004 pada pasal 7 mengatakan bahwa Indonesia telah menganut kebijakan moneter dengan tujuan tunggal yakni mencapai dan memelihara kestabilan nilai tukar rupiah. Berdasarkan surat edaran Bank Indonesia No.8/13/DPM tentang penerbitan sertifikat Bank Indonesia melalui lelang sertifikat Bank Indonesia yang selanjutnya disebut SBI adalah surat berharga dalam mata uang rupiah yang diterbitkan oleh Bank Indonesia sebagai pengakuan utang berjangka waktu pendek.

Tujuan penerbitan sertifikat Bank Indonesia sebagai otoritas moneter, BI berkewajiban memelihara kestabilan nilai rupiah. Dalam paradigma yang dianut, jumlah uang primer (uang kartal + uang giral di BI) yang berlebihan dapat mengurangi kestabilan nilai rupiah. Dengan demikian suku bunga SBI yang diterbitkan dan dijual oleh BI untuk mengurangi kelebihan uang primer tersebut, dan akan membuat rupiah menjadi terapresiasi terhadap mata uang asing.

Neraca transaksi berjalan atau current account menunjukan transaksi internasional yang terdiri dari barang, jasa dan transfer unilateral yang dihasilkan dalam periode waktu tertentu. Transaksi ekspor impor barang dan jasa dicatat dalam neraca barang dan jasa, atau balance on goods and service. Bantuan atau hiba luar negeri dicatat dalam dalam transfer unilateral.

Kenaikan atau surplus dari neraca perdagangan akan diinterpretasikansebagai indikasi awal kemungkinan terjadinya apresiasi suatu mata uang. Sebaliknya penurunan atau defisit neraca perdagangan dan neraca pembayaran akan diterjemahkan sebagai indikasi awalnya terjadi depresiasi mata uang suatu negara.

Sertifikat Bank Indonesia (SBI) adalah surat berharga yang diterbitkan oleh Bank Indonesia dan merupakan salah satu komponen yang digunakan pemerintah untuk mengendalikan jumlah uang beredar. Tingkat suku bunga 
SBI merupakan acuan bagi tingkat pengembalian yang didapatkan oleh investor apabila berinvestasi pada investasi yang bebas risiko.

\section{Cadangan Devisa}

Cadangan devisa atau foreign exchange reserves adalah simpanan mata uang asing oleh bank sentral dan otoritas moneter. Simpanan ini merupakan asset bank sentral yang tersimpan dalam beberapa mata uang cadangan (reserve currency) seperti dolar, euro, atau yen, dan digunakan untuk menjamin kewajibannya, yaitu mata uang lokal yang diterbitkan, dan cadangan berbagai bank yang disimpan di bank sentral oleh pemerintah atau lembaga keuangan.

Cadangan devisa adalah alat pembayaran luar negeri yang antara lain berupa emas, uang kertas asing dan tagihan lainnya dalam valuta asing kepada pihak luar negeri. Secara teoritis, cadangan devisa adalah aset eksternal yang memenuhi kriteria sebagai berikut: yaitu likuid, dalam denominasi mata uang asing utama, di bawah kontrol otoritas moneter, dan dapat dengan segera digunakan untuk penyelesaian transaksi internasional. Cadangan devisa meliputi emas moneter (monetary gold), hak tarik khusus (Special Drawing Rights), posisi cadangan di IMF (Reserve Position in the Fund), cadangan dalam valuta asing (foreign exchange), dan tagihan lainnya (other claims).

Sumber-sumber Devisa

1. Pinjaman / hutang luar negeri

2. Hadiah, bantuan atau sumbangan luar negeri

3. Penerimaan deviden atau jasa serta bunga dari luar negeri

4. Hasil ekspor barang dan jasa

5. Kiriman valuta asing dari luar negeri

6. Wisatawan yang belanja di dalam negeri

7. Pungutan bea masuk

b. Peranan Cadangan Devisa

Devisa diperlukan untuk membiayai impor dan membayar utang luar negeri, dimana pengelolaannya dilakukan oleh Bank Indonesia berdasarkan UU No.23 Tahun 1999 pasal 13. Pengelolaan itu dilakukan dengan melalui berbagai jenis transaksi devisa yaitu menjual, membeli, dan atau menempatkan devisa, emas dan surat-surat berharga secara tunai atau berjangka termasuk pemberian pinjaman.Hubungan antara kurs dengan cadangan devisa dapat dijelaskan melalui mekanisme harga

Menurut teori Keynesian mengatakan bahwa apabila karena suatu hal nilai tukar valuta mengalami apresiasi ( mata uang asing meningkat dan mata uang lokal menurun), maka hal ini secara relatif dapat menyebabkan tingginya harga barang ekspor dibanding harga barang impor. Kondisi ini berpengaruh pada peningkatan ekspor dan penurunan impor. Apabila ekspor lebih besar dari pada impor, maka hal ini dapat menyebabkan surplus pada Neraca Pembayaran Internasional yang selanjutnya akan meningkatkan posisi 
cadangan devisa suatu negara. Demikian sebaliknya. Oleh karena itu menurut teori Keynesian, dengan asumsi ceteris paribus, hubungan antara kurs dengan cadangan devisa adalah negatif, (Nopirin, 2008).

\section{Nilai Tukar}

Kurs valuta asing adalah salah satu alat pengukur lain yang digunakan dalam menilai kekuatan suatu perekonomian. Kurs menunjukkan banyaknya uang dalam negeri yang diperlukan untuk membeli satu unit valuta asing tertentu. Kurs valuta asing dapat dipandang sebagai harga dari suatu mata uang asing. Salah satu faktor penting yang mempengaruhi kurs valuta asing adalah neraca perdagangan nasional.

Nilai tukar valuta asing adalah harga satu satuan mata uang dalam satuan mata uang lain. Nilai tukar valuta asing ditentukan dalam pasar valuta asing yaitu pasar tempat berbagai mata uang yang berbeda diperdagangkan.

\section{KERANGKA PEMIKIRAN}

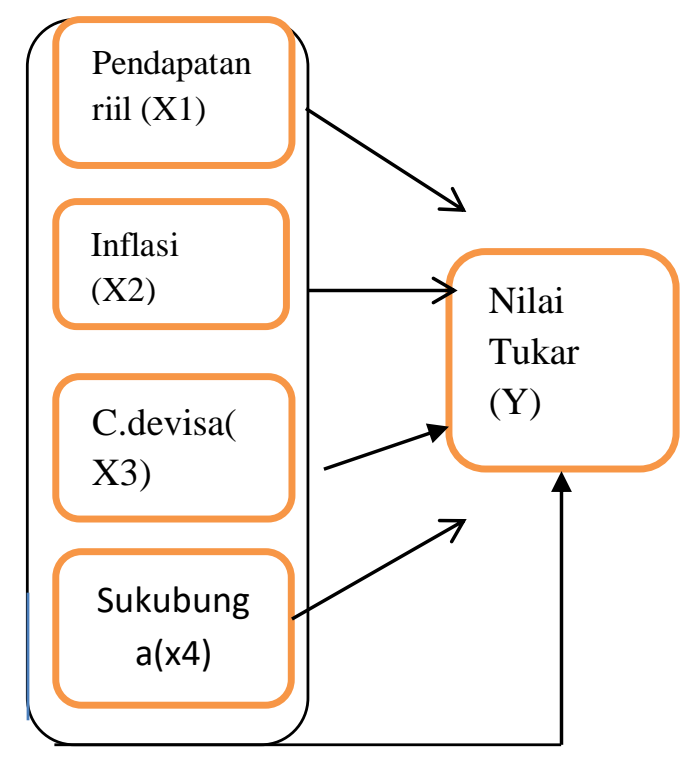

\section{Hipotesis Penelitian}

1. H0 : Pendapatan riil tidak berpengaruh signifikan terhadap perubahan nilai tukar rupiah.

H1 : Pendapatan riil berpengaruh signifikan terhadap perubahan nilai tukar rupiah.

2. H0 : Inflasi tidak berpengaruh signifikan terhadap perubahan nilai tukar rupiah. 
$\mathrm{H} 2$ : Inflasi berpengaruh signifikan terhadap perubahan nilai tukar rupiah..

3. H0 :cadangan devisa tidak berpengaruh signifikan terhadap perubahan nilai tukar rupiah.

H3 : Inflasi berpengaruh signifikan terhadap perubahan nilai tukar rupiah..

4. H0 : Tingkat suku bunga tidak berpengaruh signifikan terhadap perubahan nilai tukar rupiah.

H4 : Tingkat suku bunga berpengaruh signifikan terhadap perubahan nilai tukar rupiah.

5. H0 : Pendapatan riil, inflasi dan tingkat suku bunga tidak berpengaruh signifikan secara simultan terhadap perubahan nilai tukar rupiah.

H4 : Pendapatan riil, inflasi daan tingkat suku bunga berpengaruh signifikan secara simultan terhadap perubahan nilai tukar rupiah.

\section{Penelitian Terdahulu}

1. Adwin Sura Atmaja (2002), Menganalisis pergerakan nilai tukar rupiah terhadap dollar Amerika setelah diterapkannya kebijakan sistem nilai tukar mengambang bebas di Indonesia. Penelitian ini menganalisa tentang hubungan berbagai variabel ekonomi, yaitu tingkat inflasi, tingkat suku bunga, jumlah uang beredar, pendapatan nasional di Indonesia dan Amerika Serikat, serta posisi neraca pembayaran internasional Indonesia, dalam mempengaruhi pergerakan nilai tukar rupiah terhadap dollar Amerika, dengan tujuan untuk memberikan kontribusi pemikiran terhadap proses pemecahan masalah tersebut. Dari analisis data yang diperoleh bahwa hanya variabel jumlah uang yang beredar yang memiliki pengaruh yang signifikan terhadap pergerakan nilai tukar rupiah terhadap dollar Amerika, sedangkan variabel-variabel yang lainnya tidak.

2. Deviana Komenaung, Anderson Kumenaung, Audien Niodie (2014), Analisis pengaruh fluktuasi nilai tukar rupiah terhadap ekspor di provinsi Gorontalo. Tujuan penelitian ini adalah untuk mengetahui seberapa besar pengaruh fluktuasi nilai tukar rupiah terhadap ekspor di provinsi Gorontalo, yang merupakan provinsi yang sedang berkembang. Pada penelitian ini menggunakan bank umum secara keseluruhan sebagai satu unit obyek penelitian, dengan penelitian yang dimulai pada Januari 2009- Desember 2012. Teknik analisis yang digunakan adalah regresi linear sederhana, 
sementara uji hipotesis menggunakan uji -t untuk menguji pengaruh variabel secara parsial, koofisisen determinasi $\left(R^{2}\right)$ untuk menguji kemampuan model regresi dalam menerangkan variasi variabel terikat. Berdasarkan penelitian diperoleh bahwa nilai tukar berpengaruh positif dan signifikan terhadap ekspor.

3. Diah Fitri Julianti (2004) Analisis Faktor-faktor penentu perubahan nilai tukar rupiah. Penelitian ini bertujuan untuk menganalisis faktor-faktor yang menentukan perubahan nilai tukar rupiah selama periode 1994-2003. Serta menganalisis teori apa yang paling sesuai dengan kondisi Indonesia. Teori yang digunakan adalah flexible price, sticky price dan portofolio balances. Metode analisis yang digunakan dalam penelitian ini adalah Ordinary Least Square (OLS). Variabel-variabel yang digunakan adalah jumlah uang yang beredar, pendapatan nasional riil, tingkat suku bunga nominal, tingkat inflasi dan kekayaan. Variabel-variabel tersebut merupakan variabel dari dua negara yaitu Indonesia dan Amerika Serikat. Selain itu terdapat dua tambahan variabel yaitu dummy krisis serta kondisi sosial dan keamanan. Hasil dri penelitian adalah model yang sesuai dengan kondisi Indonesia adalah model sticky price.

4. Triyono (2008), analisis perubahan kurs rupiah terhadap dollar Amerika. Penelitian ini menggunakan data sekunder yang terdiri dari satu variabel terikat yaitu kurs dan empat variabel bebas yaitu jumlah uang yang beredar, inflasi, tingkat suku bunga SBI, dan nilai impor. Data sekunder ini berasal dari bank Indonesia. Alat analisis yang digunakan dalam penelitian ini adalah regresi linear berganda. Model yang digunakan adalah Error Corection Model (ECM). Dari hasil ECM Nampak bahwa hasil ECT sebesar 0,483191 pada derajat $\alpha=5 \%$. Hal ini berarti nilai ECT tersebut sudah memenuhi kriteria yaitu $0<\mathrm{ECT}<1$. Dengan kata lain model ECM dalam penelitian ini dapat dipakai untuk menganalisis pengaruh variabel bebas.

\section{METODE PENELITIAN}

\section{Lokasi Penelitian}


Penelitian ini dilakukan pada Bank Indonesia . Bank Indonesia selaku bank sentral berdasarkan pasal 4 ayat 1 UU RI No. 23 tahun 1999 adalah lembaga negara yang independen dan memiliki satu tujuan yakni mencapai dan memelihara kestabilan rupiah.

\section{Jenis dan Sumber Data}

Data yang digunakan dalam penelitian ini adalah data sekunder dalam bentuk deret waktu ( time series ) triwulan periode 2006-2018. Data sekunder berasal dari laporan statistik ekonomi keuangan Bank Indonesia (SEKI BI), dan laporan tahunan perekonomian indonesia dan Badan Pusat Statistik (BPS)

\section{Teknik Analisis Data}

\section{Analisis Regresi linear Berganda}

Hipotesis dalam penelitian ini diuji dengan menggunakan model analisis regresi linear berganda untuk memperoleh gambaran pengaruh antar variabel dependen yaitu nilai tukar dan variabel independennya: (Suliyanto, 2010).

$$
\mathrm{Y}=\mathrm{a}+\mathrm{b}_{1} \mathrm{X}_{1}+\mathrm{b}_{2} \mathrm{X}_{2}+\mathrm{b}_{3} \mathrm{X}_{3}+\mathrm{b} 4 \mathrm{X} 4+\mathrm{e}
$$

Keterangan :

$$
\begin{array}{ll}
\mathrm{Y} & =\text { nilai tukar rupiah } \\
\mathrm{a} & =\text { konstanta } \\
\mathrm{b}_{1} & =\text { koofisien regresi variabel pendapatan riil } \\
\mathrm{b}_{2} & =\text { koofisien regresi variabel inflasi } \\
\mathrm{b} 3 & =\text { koofisien regresi variabel cadevisa } \\
\mathrm{b}_{4} & =\text { koofisien regresi variabel suku bunga } \\
\mathrm{e} & =\text { error }
\end{array}
$$

\section{Partial Test (Uji T)}

Partial test dilakukan untuk menguji apakah hipotesis variabel independen berpengaruh secara individual terhadap variabel dependen dengan menggunakan analisis uji t. Pengujian ini dilakukan dengan membandingkan nilai t hitung dengan $t$ tabel dengan tingkat kepercayaan $\propto$ sebesar $5 \%(0,05)$.

\section{Simultan Test (Uji F)}

Simultan test ini dilakukan untuk menguji variabel bebas yang secara bersam-sama (simultan) berpengaruh terhadap variabel terikat. Dengan menggunakan analisis uji $\mathrm{F}$ yaitu membandingkan nilai antara $\mathrm{F}$ hitung dengan F tabel dengan tingkat signifikansi 0,05 .

\section{Uji Asumsi Klasik}


Untuk mengetahui apakah hasil estimasi regresi yang dilakukan terbebas dari yang mengakibatkan hasil regresi yang diperoleh tidak valid dan akhirnya hasil regresi tersebut tidak dapat dipergunakan sebagai dasar untuk menguji hipotesis dan penarikan kesimpulan, maka digunakan asumsi klasik.

\section{Uji Normalitas Data}

Pengujian dilakukan dengan melihat penyebaran data (titik) pada sumbu diagonal dari grafik scatter plot, dasar pengambilan keputusannya adalah jika data menyebar disekitar garis diagonal dan mengikuti garis diagonal maka model regresi memenuhi asumsi normalitas. Jika data menyebar jauh dari regresi atau tidak mengikuti arah garis diagonal, maka model regresi tidak memenuhi asumsi normalitas.

\section{Uji Multikolonieritas}

Tujuan utama adalah untuk menguji apakah pada model regresi ditemukan adanya korelasi antar variabel independen digunakan untuk mendeteksi ada tidaknya multikolonieritas dalam penelitian adalah dengan menggunakan Variance Inflation Factor (VIF) yang merupakan kebalikan dari toleransi sehingga formulanya adalah sebagai berikut: $V I F=\frac{1}{\left(1-R^{2}\right)}$ dimana $\mathrm{R}^{2}$ merupakan koofesien determinasi. Bila korelasi kecil artinya menunjukkan nilai VIF akan besar. Bila VIF >10 maka dianggap ada multikolonieritas dengan variabel bebas lainnya. Sebaliknya VIF $<10$ maka dianggap tidak terdapat multikolonearitas.

\section{Uji Heterokedastisitas}

Pengujian Heterokedastisitas dalam model regresi dilakukan untuk mengetahui apakah dalam model regresi terjadi ketidaksamaan varians dan dari suatu pengamatan yang lain. Dasar pengambilan keputusannya adalah:

a. Jika ada pola tertentu seperti titik-titik yang ada membentuk suatu pola yang teratur (bergelombang melebar kemudian menyempit) maka telah terjadi heterokedastisitas.

b. Jika tidak terdapat pola yang jelas serta titik-titik menyebar diatas dan di bawah angka 0 (nol) pada sumbu Y maka tidak terjadi heterokedastisitas.

\section{Uji Autokorelasi}

Uji Autokorelasi merupakan korelasi atau hubungan yang terjadi antara anggota-anggota dari serangkaian pengamatan yang tersusun dalam times series pada waktu yang berbeda. Autokorelasi bertujuan untuk menguji apakah dalam 
sebuah model regresi linear ada korelasi antara kesalahan pengganggu pada periode t. Jika ada, berarti terdapat Autokorelasi. Dalam penelitian ini keberadaan Autokorelasi diuji dengan Durbin Watson

\section{Koefisien Determinasi $\left(\mathbf{R}^{\mathbf{2}}\right)$}

Koefisien Determinasi $\left(\mathrm{R}^{2}\right)$ adalah sebuah koefisien yang menunjukkan persentase pengaruh semua variabel independen terhadap variabel dependen. Persentase tersebut menunjukkan seberapa besar variabel independen (pendapatan riil, inflasi dan suku bunga), dapat menjelaskan variabel dependen (nilai tukar). (Priyanto, 2010).

\section{HASIL DAN PEMBAHASAN}

\section{Analisis Regresi Linier Berganda}

$\mathrm{Y}=\mathrm{a}+\mathrm{b}_{1} \mathrm{X}_{1}+\mathrm{b}_{2} \mathrm{X}_{2}+\mathrm{b}_{3} \mathrm{X}_{3}+\mathrm{b} 4 \mathrm{X} 4+\mathrm{e}$

Keterangan : $\mathrm{Y} \quad$ : Nilai tukar rupiah

$\begin{array}{ll}\text { a } & \text { : konstanta } \\ \mathrm{b} & \text { : koefisien regresi } \\ \mathrm{x} 1 & \text { : Pendapatan rill } \\ \mathrm{x} 2 & \text { : Inflasi } \\ \mathrm{x} 3 & \text { : Suku bunga } \\ \mathrm{e} & \text { : error }\end{array}$

Dari output pada tabel 4.1 dapat dilihat persamaan regresi yaitu : $\mathrm{Y}=24291,729-1704,824 \mathrm{X} 1+202,857 \mathrm{X} 2-0.018$ X3-648,669X4+e

Dengan artian sebagai berikut :

1. Nilai konstanta (a) sebesar 24291,729. Artinya adalah apabila $X_{1}$ (Pendapatan rill), $\mathrm{X}_{2}$ (inflasi) dan $\mathrm{X}_{3}$ (suku bunga ) diasumsikan nol (0), maka Y (nilai tukar) bernilai 24291,729

2. Koefisien regresi variabel pendapatan rill $\left(\mathrm{X}_{1}\right)$ sebesar $-1704,824$. Artinya adalah bahwa setiap peningkatan terhadap variabel pendapatan rill sebesar 1 satuan maka akan menurunkan nilai tukar rupiah sebesar -1704,824

3. Koefisien regresi variabel inflasi $\left(\mathrm{X}_{2}\right)$ sebesar 202,857. Artinya adalah bahwa setiap peningkatan terhadap variabel inflasi sebesar 1 satuan maka akan meningkatkan nilai tukar rupiah sebesar 202,857

4. Koefisien regresi variabel cadev bunga $\left(\mathrm{X}_{3}\right)$ sebesar - 0.018. Artinya adalah bahwa setiap peningkatan terhadap variabel suku bunga sebesar 1 satuan maka menurunkan nilai tukar rupiah sebesar - 0.018

5. Koefisien regresi variabel suku bunga $\left(X_{3}\right)$ sebesar 648,669. Artinya adalah bahwa setiap peningkatan terhadap variabel suku bunga sebesar 1 satuan maka akan menurunkan nilai tukar rupiah sebesar 648,669 
6. Standar error (e) merupakan variabel acak dan mempunyai distribusi probabilitas yang mewakili semua faktor yang mempunyai pengaruh terhadap Y tetapi tidak di masukkan dalam persamaan.

\section{Uji Signifikansi Parsial (Uji-t)}

Berdasarkan tabel 4,1 dapat dijelaskan uji t pada tiap variabel sebagai berikut :

Tabel 4.1 Uji parsial

\begin{tabular}{|l|l|ll|}
\hline variabel & coefisisent & \multicolumn{2}{|l|}{ T hitung sign } \\
\hline a & 24292,729 & 5,617 & 0,001 \\
X1 & $-1704,824$ & $-2,301$ & 0,005 \\
X2 & 202,857 & 1,173 & 0,275 \\
X3 & $-0,018$ & $-2,094$ & 0,070 \\
X4 & $-648,669$ & $-2,414$ & 0,042 \\
\hline \multicolumn{2}{|l}{ Sumber : data olahan 2019}
\end{tabular}

T tabel diperoleh sebesar 2, 284 :

Berdasarkan hasil t hitungdapat dijelaskan sebagai berikut:

1. Variabel pendapatan rill (X1) menunjukkan nilai $t_{\text {hitung }}>t_{\text {tabel }}$ atau 2.,301 > 2,284 dan Sig. 0,000 < 0,05, artinya variabel pendapatan rill berpengaruh signifikan terhadap nilai tukar rupiah.

2. Variabel inflasi (X2) menunjukkan nilai $t_{\text {hitung }}<t_{\text {tabel }}$ atau artinya variabel inflasi berpengaruh tidak signifikan terhadap nilai tukar

3. Variabel cadangan devisa (X3) menunjukkan nilai $t_{\text {hitung }}<t_{\text {tabel }}$ atau artinya variabel cadev berpengaruh tidak signifikan terhadap nilai tukar

4. Variabel suku bunga (X4) menunjukkan nilai thitung $>t_{\text {tabel }}$ artinya variabel Suku bunga berpengaruh signifikan terhadap nilai tukar

\section{Uji signifikansi Simultan (Uji F)}

\section{Tabel 4.2 Uji F}

\begin{tabular}{|l|l|l|l|}
\hline model & df & f & sign \\
\hline Regression & 4 & 6,337 & 0,013 \\
Residual & 8 & & \\
Total & 12 & & \\
\hline
\end{tabular}

F tabel: 4,718

Sumber : Data olahan 2019 
Berdasarkan kriteria penilaian uji F dikatakan fix (sesuai) jika $F_{\text {hitung }}>F_{\text {tabel. }}$ berdasarkan tabel uji $\mathrm{f}$ dan persamaan $\mathrm{f}$ tabel diatas diketahui bahwa $\mathrm{F}_{\text {hitung }}(6,337)$ $>\mathrm{F}_{\text {tabel }}(4,718)$ dengan Sig. $0.001<0,05$, yang berarti $\mathrm{H}_{0}$ ditolak dan $\mathrm{H}_{\mathrm{a}}$ di terima. Hal ini menunjukkan bahwa variabel pendapatan rill, inflasi cadangan devisa dan suku bunga secara simultan berpengaruh signifikan terhadap nilai tukar rupiah.

\section{Koefisien Determinasi $\left(\mathbf{R}^{2}\right)$}

Uji koefisien determinasi $\left(\mathrm{R}^{2}\right)$ bertujuan untuk mengetahui kekuatan atau kontribusi variabel bebas terhadap variabel terikat. Dalam penelitian ini uji koefisien determinasi $\left(\mathrm{R}^{2}\right)$ bertujuan untuk mengetahui seberapa bebas kekuatan atau kontribusi pengaruh variabel independen (pendapaatn rill, inflasi dan suku bunga) terhadap variabel dependen (nilai tukar rupiah). Perhitungan menggunakan program SPSS versi 20. Hasil dari uji koefisien determinasi $\left(\mathrm{R}^{2}\right)$ dilihat pada tabel berikut:

Tabel 4.3. Koefiseien Determinasi

\begin{tabular}{|l|r|r|r|r|r|}
\hline \multirow{2}{*}{$\begin{array}{l}\text { Mod } \\
\text { el }\end{array}$} & $\begin{array}{c}\text { R Square } \\
\text { Change }\end{array}$ & F hitung & df1 & df2 & Sig. F \\
\cline { 2 - 6 } 1 & $.760^{a}$ & 6.337 & 4 & 8 & .013 \\
\hline
\end{tabular}

Sumber : Data olahan 2019

Hasil pada tabel model summary diatas dapat dijelaskan bahwa korelasi (R) antara variabel independen (pendapaatn rill, inflasi dan suku bunga) terhadap variabel dependen (nilai tukar rupiah) menunjukkan nilai sebesar 0,620 Artinya hubungan antara variabel independen (pendapaatn rill, inflasi dan suku bunga) terhadap variabel dependen (nilai tukar rupiah) sebesar 76,0\%.

Koefisien determinasi $\left(\mathrm{R}^{2}\right)$ pada tabel diatas menunjukkan nilai sebesar $76 \%$ artinya variabel independen (pendapatan rill, inflasi dan suku bunga) mampu menjelaskan variabel dependen (nilai tukar rupiah) sebesar 24\%. Selebihnya dijelaskan oleh variabel lain yang tidak diteliti dalam penelitian ini. Nilai Adjusted $R$ square pada tabel diatas merupakan koefisien determinasi yang telah disesuaikan untuk menghindari bias menunjukkan nilai 0,326 atau 32,6.\%

\section{Uji Asumsi Klasik}


Uji asumsi klasik bertujuan untuk mengukur keabsahan atau ketepatan penggunaaan variabel dalam penelitian. Metode uji asumsi klasik yang digunakan yaitu:

Uji Normalitas

Gambar 1 Output Uji normalitas dengan histogram

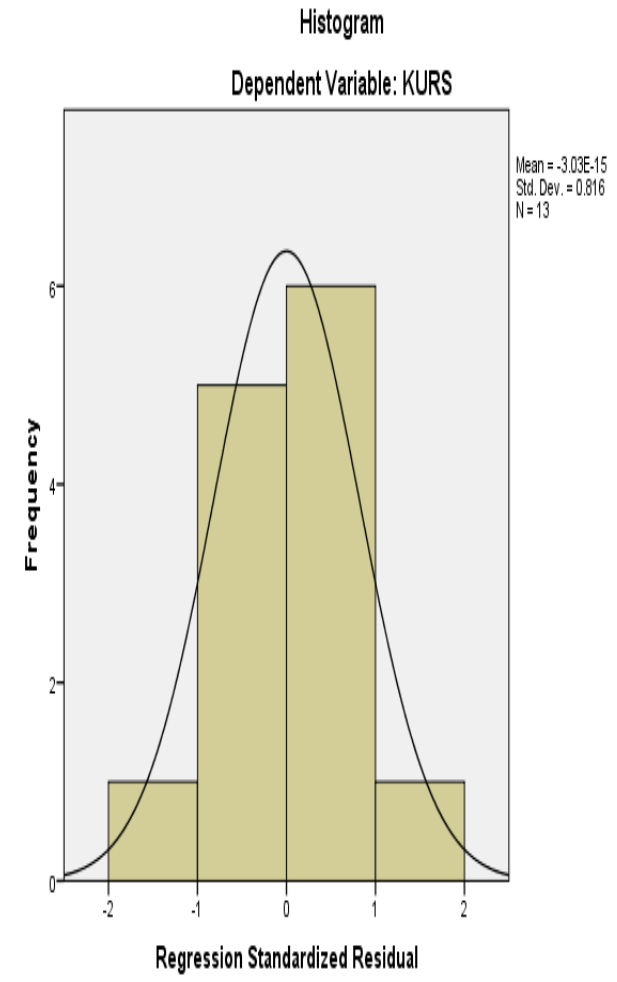

Berdasarkan tampilan histogram terlihat bahwa kurva dependent dan regression standardized residual membentuk gambar seperti lonceng. Oleh karena itu berdasarkan uji normalitas, analisis regresi layak digunakan meskipun sedikit terdapat kemiringan.

Sedangkan hasil output Normal P-Plot Regression standardized menunjukkan hasil berikut:

Gambar 2 Output uji Normalitas Normal P-Plot of Regression Standarized Residual 


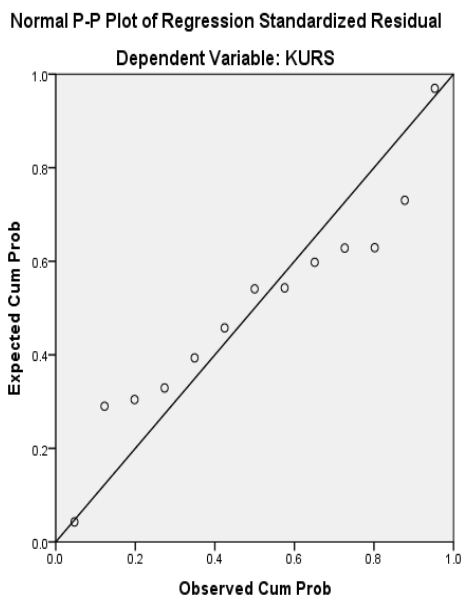

Berdasarkan tampilan Normal P-Plot Regression standardized terlihat bahwa titik-titik menyebar disekitar garis diagonal. Oleh Karena itu berdasarkan uji normalitas, analisis regresi layak digunakan meskipun terdapat sedikit plot yang menyimpang dari garis diagonal.

\section{Uji Multikolineritas}

Tujuan utama pengujian multikolinieritas adalah untuk menguji apakah pada model regresi ditemukan adanya korelasi antar variabel independen digunakan. Dalam penelitian ini untuk mengetahui apakah ada korelasi antar veriabel bebas yaitu pendapatan rill, inflasi dan suku bunga terhadap variabel terikat yaitu nilai tukar rupiah. Untuk mendeteksi ada tidaknya multikolinieritas dalam penelitian adalah dengan menggunakan Variance Inflation Factor (VIF) yang merupakan kebalikan dari toleransi.

Tabel 4.4 Output uji multikolineritas dengan Variance Inflation Factor (VIF) menggunakan program SPSS

\section{Coefficients $^{\mathrm{a}}$}

\begin{tabular}{|ll|r|c|}
\hline \multirow{2}{*}{ Model } & \multicolumn{2}{c|}{$\begin{array}{c}\text { Collinearity } \\
\text { Statistics }\end{array}$} \\
\cline { 2 - 4 } & & Tolerance & VIF \\
\hline 1 & Pendapatan riil & .469 & 2.131 \\
& TK INFLASI & .427 & 2.341 \\
& CAD DEVISA & .755 & 1.325 \\
& sukubunga & .614 & 1.629 \\
\hline
\end{tabular}

a. Dependent Variable: KURS

Sumber : data olahan 2019 
Berdasarkan kriteria penilaian jika nilai VIF kurang dari 10 maka tidak tedapat gejala multikolineritas. Oleh karena itu variabel yang digunakan dalam penelitian ini terhindar dari gejala multikolineritas.

\section{Uji Autokorelasi}

Uji autokorelasi bertujuan untuk mengetahui apakah ada korelasi antara anggota serangkaian data observasi yang diuraikan menurut waktu (time-series) atau ruang (cross-section). Dalam penelitian ini keberadaan Autokorelasi diuji dengan Durbin Watson menggunakan program SPSS versi 20 dengan hasil output sebagai berikut:

\section{Tabel 4.5 Output uji autokorelasi Durbin watson}

\begin{tabular}{|l|c|}
\multicolumn{1}{c}{ Model Summary $^{\mathrm{b}}$} \\
\hline Model & Durbin-Watson \\
\hline 1 & $1.634^{\mathrm{a}}$ \\
\hline
\end{tabular}

a. Predictors: (Constant), sukubunga, PRTUMBUHAN EKO, CAD DEVISA, TK

INFLASI

b. Dependent Variable: KURS

Sumber : Data olahan 2014

a. Bila DW dibawah -2 : terdapat autokorelasi positif

b. Bila DW antara -2 sampai +2 : tidak terdapat autokorelasi

c. Bila DW diatas +2 : terdapat autokorelasi negatif

Berdasarkan Tabel 4.5 bisa dilihat bahwa variabel-variabel dalam penelitian ini juga memenuhi bebas dari autokrelasi. penelitian . Hal ini bisa dilihat dari nila durbin watson yang terletak antara -2 dan +2 .

\section{Uji Heteroskedasitas}

Pengujian terhadap assumsi mklasik yang terakhir adalah dengan dengan melihat apakah variabel@ dalam penelitian ini lolos uji heteroskedastisitas.

Tujuannya untuk menguji apakah model regresi terjadi ketidaksamaan varians dari residual dari 1 pengamatan yang lain. Model regresi yang baik adalah tidak terjadi heteroskedasitas. Pengujian dilakukan dengan melihat ada tidaknya pola pada grafik dimana sumbu $\mathrm{Y}$ adalah $\mathrm{Y}$ yang telah diprediksikan dan sumbu X adalah residual (Y) prediksi-Y sesungguhnya. 


\section{Gambar 3 Output uji heteroskedasitas}

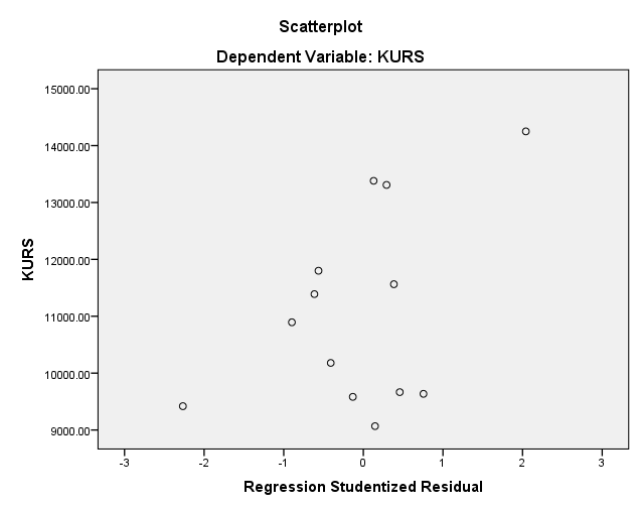

Sumber : Data olahan 2019

Berdasarkan tampilan pada scatter plot terlihat bahwa plot menyebar secara acak diatas maupun dibawah angka sumbu regression studentized residual oleh karena itu berdasarkan uji heteroskedasitas mengggunakan metode analisisi grafik, pada model regresi yang terbentuk dinyatakan tidak terjadi gejala heteroskedasitas.

\section{Analisis Pembahasan:}

Secara makro ekonomi ada banyak faktor yang mempengaruhi Kurs. Dalam penelitian ini yang dibahas adalah Pendapatan Riil (pertumbuhan Ekonomi), Inflasi, Cadangan devisa dan suku bunga.

Indoesia sebagai negara yang menetapkan sistem kurs mengambang, maka nilai perbandingan mata uamg asing dengan mata uang domestik amat sangat fluktuatif.. Perubahan-perubahan yang terjadi pada negara-negara maju akan berdampak kepada perekonomian makro Indonesia.

Dalam penelitian ini ditemukan bahwa pertumbuhan ekonomi signifikan berepngaruh terhadap kurs. hubungan yang terjadi adalah positif Secara teori, pertumbuhan ekonomi yang tinggi maka akan berdampak kepada kondisi kurs yang juga akan menguat. Namun harus diingat juga bahwa pertumbuhan ekonomi yang dihasilkan oleh sebuah negara tetapi tidak dengan memperhatikan sumberdayasumberdaya yang dimilki, maka tidak akan memperkuat pondasi perekonomian justru akan memperlemah. Apabila petrtumbuhan ekonomi dihasilkan dari penggunaan sumberdaya-sumberdaya yang berasal dari luar (tenaga kerja, bahan baku) atau kalau pun sumberdayta alam dalam negri tapi oleh perusahaanperusahaan asing, maka meskipun pertumbuhan ekonomi sebuah negara maju,atau 
tinggi tetapi tidak dapat mencerminkan keberhasilan di dalam perekonomian itu sendir.

Kenapa ini terjadi ? karena penguasaan sumberdaya-sumberdaya tersebut tidak dimilki oleh dalam nergri tapi dikuasai oleh asing, diexploitasi sumberdaya oleh asing, yang kemudian hasilnya dibawa keluar dari Indonesia. Ini bisa terjadi karena memang dalam ilmu ekonomi pembangunan dikenal adanya konsep trickle down effect, yaitu konsep menetes ke bawah. Bila perekonomian ingin menggunakan prioritas pada pertumbuhan maka harus memperhatikan aspek menetes ke bawah, artinya harus ada manfaar bagi masyarakat Indonesia atau sekitar. Kalau tidak maka yang terjadi adalah pertumbuhan ekonomi justru berbanding terbalik dengan kondisi yang diharapkan.

Untuk inflasi, dalam penelitian ini didapat hubungan yang negatif antara inflasi dengan kurs. Dalam teori Purchasing Power Parity disebutikan bahwa kurs mata uang akan berubah untuk mempertahankan daya belinya. Bila inflasi domestik lebih tinggi dari inflasi luar negri, maka mata uang domestik akan terdepresiasi. Dari data Selama tahun 2006-2018, diperoleh hubungan yang negatif dan tidak signifikan antara kurs dengan inflasi. Melonjaknya harga_harga kebutuhan pokok dan kebijakan menaikkan tarif listrik, BBM yang dilakukan oleh pemerintah, secara langsung akan semakin membuat tingginya tingkat inflasi yang terjadi. Inflasi yang terjadi berbanding terbalik dengan kurs dan tidak signifikan.

Hubungan antar cadangan devisa dengan kurs, dalam penelitian ini negatif dan tidak signifikan.

Secara teori terdapat hubungan yang erat antar cadangan devisa dengan kurs. bisa dijelaskan sebagai sebuah hubungan yang erat.

Ini menjadi penting Kenapa diaktakan erat?arena struktur perekonomian Indonesia yang berasal dari export adalah berbasis pada sumberdaya alam. Terdapat beberapa kelemahan dan kerugian yang diterima oleh Indonesia berkaitan dengan kebijakan sumberdaya alama ini.

Cadangan devisa yang meningkat hanya akan meningkat bila terjadi Export yang melebihi dari pada Import. Artinya ada banyak permibtaan terhadap produk@ lokal Indonesia oleh luar negri, ketimbang permintaan Indoenesia terhadap produkproduk dari luar negri. Cadangan devisa hanya akan didapat apabila Export lebih besar dari import. Sementara kita mengetahui untuk saat ini eksport Indoensia untuk komoditi baik pertanian atau non prtanian (padat kapital atau padat labor) betulbetul pada kondisi paling rendah. Untuk komoditi yang sedrhana saja dan sumberday yang melimpah dimilki pun Indoensia banyak melakukan import. 
Hubungan antara kurs dengan cadangan devisa dapat dijelaskan melalui mekanisme harga. Menurut teori Keynesian mengatakan bahwa apabila karena suatu hal nilai tukar valuta mengalami apresiasi ( mata uang asing meningkat dan mata uang lokal menurun), maka hal ini secara relatif dapat menyebabkan tingginya harga barang ekspor dibanding harga barang impor. Kondisi ini berpengaruh pada peningkatan ekspor dan penurunan impor. Apabila ekspor lebih besar dari pada impor, maka hal ini dapat menyebabkan surplus pada Neraca Pembayaran Internasional yang selanjutnya akan meningkatkan posisi cadangan devisa suatu negara. Demikian sebaliknya. Oleh karena itu menurut teori Keynesian, dengan asumsi ceteris paribus, hubungan antara kurs dengancadangan devisa adalah negatif,

Dalam penelitian ini Suku bunga dengan kurs, hubungannya positif dan signifikan. ingkat suku bunga menentukan nilai tambah mata uang suatu negara. Semakin tinggi suku bunga suatu mata uang, akan semakin tinggi pula permintaan akan mata uang negara tersebut. Tingkat suku bunga diatur oleh bank sentral, dan jika dalam jangka panjang bank sentral selalu menaikkan suku bunga maka trend nilai tukar mata uang negara tersebut terhadap negara lain akan cenderung naik. Hal ini akan terus berlangsung sampai ada faktor lain yang mempengaruhi atau bank sentral kembali menurunkan suku bunganya.

\section{Kesimpulan dan Saran}

\section{Kesimpulan}

Dari pembahasan yang telah dilakukan dapat disimpulkan sebagai berikut:

1.Secara parsial, atau uji t. Terdapat hubungan yang negatif dan signifikan terhadap pendapatan riil dan suku bunga dengan Kurs. Dan terdapat hubungan yang positif antara inflasi dengan kurs, namun tidak signifikan. Dan hubungan yang negatif dan tidak signifikan antar cadangan devisa dengan kurs.

2. Secara simultan atau uji F, secara bersama-sama variabel bebas pendapatan riil, inlasi dan suku bunga signifikan terhadap variabel tidak bebas nilai tukar

3. Koefisien Detrerminasi $\mathrm{R}$ square denelitian ini adalah nilai tukar $76,4 \%$. Artinyan sebanyak $76,4 \%$ variabel nilai tukar mampu dijelaskan oleh pendapatan riil, inflasi cadangan devisa dan tingkat sukubunga. Sisanya Sebanyak 24,62\% dijelaskan oleh variabel lain, yang tidak dibahas dalam penelitian ini.

\section{Saran}


1. Bagi pemerintah, Sebagai salah satu indikator keberhasilan suatu bangsa , Kurs dan variabel-variabel yang diteliti, amatlah penting untuk ditingkatkan, terutama saat ini. Disaat semua indikator makroekonomi menujukkan angka yang tidak menggembirakan.

2. Bagi peneliti selanjutnya, diharapkan dapat menambahkan variabel variabel lain seperti investasi, exsport import dan lain-lain, sehingga dapat dilihat perubahan nilai tukar dengan lebih lengkap.

\section{DAFTAR PUSTAKA}

Anggaristyadi, Galih. 2011. Analisis pengaruh pendapatan perkapita, nilai tukar Rupiah terhadap dolar, cadangan devisa dan inflasi Terhadap perkembangan impor indonesia tahun 1985 - 2008. Skripsi Tidak Dipublikasikan Universitas Sebelas Maret Surakarta (Online- http:// http://eprints.uns.ac.id/18319/1/GALIHANGGARISTYADI.pdf, Diakses tanggal 6,juni $201410.00 \mathrm{WIB})$.

Atmaja, Adwin Surja. 2004. Analisis Pergerakan Nilai Tukar Rupiah Terhadap Dollar Setelah Diterapkan Kebijakan Sistem Nilai Tukar Mengambang Bebas Di Indonesia. Jurnal Akuntansi Dan Keuangan Vol, 4, No. 1 Universitas Kristen Petra. ( onlinehttp://cpanel.petra.ac.id/ejournal/index.php/aku/article/view/15691/15683 - diakses tanggal 30 April 2018, 09:00 WIB)

Bank Indonesia. 2006. Laporan Tahunan Bank Indonesia 2006. BI. Jakarta. (Online- http://bi.go.id/-diakses tanggal 15 Januari 2019, 15:20 WIB)

. 2007. Laporan Tahunan Bank Indonesia 2007. BI. Jakarta. (Online- http://bi.go.id/-diakses tanggal 15 Januari 2014, 15:20 WIB)

. 2008. Laporan Tahunan Bank Indonesia 2008. BI. Jakarta. (Online- http://bi.go.id/-diakses tanggal 15 Januari 2014, 15:20 WIB)

. 2009. Laporan Tahunan Bank Indonesia 2009. BI. Jakarta.

(Online- http://bi.go.id/-diakses tanggal 15 Januari 2014, 15:20WIB)

. 2010. Laporan Tahunan Bank Indonesia 2010. BI. Jakarta. (Online- http://bi.go.id/- diakses tanggal 15 Januari 2014, 15:20 WIB)

. 2011. Laporan Tahunan Bank Indonesia 2011. BI. Jakarta.

(Online- http://bi.go.id/- diakses tanggal 5 Juli 2014, 11.00 WIB). 
2012. Laporan Tahunan Bank Indonesia 2012. BI. Jakarta.

(Online- http://bi.go.id/- diakses tanggal 5 Juli 2014, 11.00 WIB).

. 2013. Laporan Tahunan Bank Indonesia 2013. BI. Jakarta.

(Online- http://bi.go.id/- diakses tanggal 5 Juli 2014, 11.00 WIB).

Djalal, Nachrowi. 2005. Penggunaan Tekknik Ekonometrika. Jakarta : PT. Raja

Grafindo Persada.

Fitri Julianti, Diah. 2004. Analisis Faktor-Faktor Penentu Perubahan Nilai Tukar Rupiah. Departemen Ilmu Ekonomi Dan Studi Pembangunan Fakultas Ekonomi Dan Manajemen Institut Pertanian Bogor ( Online- http://eprints.ipb.ac.id/32111/- diakses tanggal 12 Desember 2013, 20:12 WIB)

Ghozali, Imam, 2005. Analisis Multivariate dengan Program SPSS, BP Undip, Semarang.

Harahap, Azwar, 2008, Ekonomi Moneter, Pekanbaru, UIN SUSKA PRESS.

Huda, Nurul dkk. 2009. Ekonomi Makro Islam: Pendekatan Toeritis, Kencana, Jakarta.

Jogiyanto. 2003. Teori Portofolio dan Analisis Investasi, BPFE, Yogyakarta.

Kasmir. 2010. Pengantar Manajemen Keuangan. Jakarta : Kencana

Kemaung, Deviana. 2014. Analisis Pengaruh Fluktuasi Nilai Tukar Terhadap

Ekspor Diprovinsi Gorontalo. Jurnal Berkala Ilmiah Efisiensi Vol.

14 No.1. Fakultas Ekonomi dan Bisnis Universitas Sam Ratulangi.

(Online - http://publikasi.universitassamratulangi.ac.id/ Diakses

Tanggal 30 April 2014, 08:30 WIB).

Kuncoro. 2004. Manajemen Strategi dan Kebiksanaan Bisnis. BPE UGM. Yogyakarta.

Levi, Maurice D. 2014. Keuangan Internasional. Penerbit Andi, Yogyakarta.

Letak astronomis, geografis, geologis indonesia http://sistempemerintahanindonesia.blogspot.nl/2013/12/letak-astronomis-indonesia-posisi.html (online diakses tanggal 17, Juli $201421.00 \mathrm{WIB}$ ).

Liauw, Joven Sogianto dan Wijaya, Trisnadi. 2011. Analisis Pengaruh Tingkat Inflasi, Tingkat Suku Bunga SBI dan Nilai tukar Terhadap Indeks Harga Saham Gabungan (IHSG) di Bursa Efek Indonesia. Jurnal 
STIE MDP. (Online- http:// http//eprints.stiemdp.ac.id - Diakses Tanggal 10, Juli $201420.00 \mathrm{WIB})$.

Mankiw, Gregory. 2007. Makro Ekonomi, Edisi Keenam, Jakarta, Penerbit Erlangga.

Mishkin, Frederic S. 2009. Ekonomi Uang, Perbankan, dan Pasar Keuangan

Buku 2. Terjemahan Lana Soelistianingsih dan Beta Yulianita. Jakarta Salemba Empat.

Najmudin. 2011. Manajemen Keuangan dan Aktualisasi Syar'iyah Modern. Yogyakarta : Andi Offset

Nawari. 2010, Analisis Regresi dengan MS Excel dan SPSS 17, Jakarta, PT Elex Media Komputindo

Outlook Ekonomi Indonesia Tahun 2009-2014. Publikasi Bank Indonesia ( Onlinehttp://www.bi.go.id/id/publikasi/kebijakan-moneter/outlookekonomi/Pages/oei 0109.aspx - Diakses Tanggal, 3, Mei, 2014, 10:42 WIB).

Priyatno, Dwi. 2010. Paham Analisis Statistik Data dengan SPSS. Media Kom, Yogyakarta.

Prospek Tahun 2006 Tidak Begitu Cerah. ( Online-

http://kolom.pacific.net.id/ind/prof m. sadli/artikel_prof m. sadli/prosp ek_tahun_2006_tidak_begitu_cerah.html - Diakses Tanggal 4, Juni, 2014, 10.00 WIB).

Puspitaningrum, Roshinta dkk. 2014 Pengaruh Tingkat Inflasi, Tingkat Suku Bunga SBI, dan Pertumbuhan Ekonomi Terhadap Nilai Tukar Rupiah. Jurnal Administrasi Bisnis (JAB) Vol. 8 No.1 . (Onlinehttp://administrasibisnis.studentjournal.ub.ac.id/ Diakses Tanggal 30 April 2014, 08:05 WIB).

Raharjo, Sugeng. 2009. Pengaruh Inflasi, Nilai Kurs Rupiah, dan Tingkat Suku Bunga Terhadap Harga Saham Di Bursa Efek Indonesia. Jurnal Tidak dipublikasikan. STIE AUB Surakarta (Online http// http//eprints.stie.aub.ac.id-_ Diakses Tanggal 6 mei 2018 20.00.WIB).

Salvatore, Dominick. 2004. Ekonomi Internasional, Jakarta, Penerbit Erlangga

Statistik Ekonomi Keuangan Indonesia. Berbagai Edisi. Bank Indonesia. (Onlinehttp://www.bi.go.id./web/id/Statistik/Statistik+Ekonomi+dan+ Keuang an+Indonesia - Diakses Tanggal 15, Juli 2018).

Sugiono. 2012. Metode Penelitian Bisnis. Bandung : Alfabeta. 
Sukirno, Sadono. 2004. Makro Ekonomi: Teori Pengantar, Edisi Keempat, Jakarta, PT Raja Grafindo Persada.

. 2005. Mikro Teori Pengantar, Edisi Ketiga, Jakarta, PT Raja Grafindo Persada.

. 2010. Ekonomi Pembangunan, Edisi Kedua, Jakarta, KENCANA PRENADA MEDIA GROUP.

Suliyanto. 2011. Ekonometrika Terapan: Teori \& Aplikasi dengan SPSS. Yogyakarta, Andi Offset.

Theo, William dkk, 2012. Pengaruh Suku Bunga, Inflasi dan Pendapatan Nasional Terhadap Nilai Tukar Rupiah Tahun 2008-2012. Jurusan Manajemen STIE MDP. (Onlinehttp//eprints.stiemdp.ac.id , Diakses Tanggal 5, Juni 2018. 10.00 WIB).

Triyono. 2008. Analisis Perubahan Kurs Rupiah Terhadap Dollar Amerika. Jurnal Ekonomi Pembangunan, Vol. 9, No.2, Fakultas Ekonomi Universitas Muhamadiyah Surakarta. (Onlinehttp://publikasiilmiah.ums.ac.id:8080/handle/123456789/152 Diakses Tanggal 30 April 2018, 10:05 WIB).

Utami, Mudji dan Rahayu, Mudjilah. 2003. Peranan Profitabilitas, Suku Bunga, Inflasi, dan Nilai Tukar Dalam Mempengaruhi Pasar Modal Indonesia Selama Krisis Ekonomi. Jurnal Manajemen dan Kewirausahaan Vol, 5 No. 2, Fakultas Ekonomi Universitas Surabaya.

(Onlinehttp://cpanel.petra.ac.id/ejournal/index.php/man/article/view/15639/1563 1 Diakses Tanggal 30 April 2018, 9:455 WIB) 